\title{
Assessing the Academic and Professional Development Needs of Graduate Students
}

\author{
Laurie Bellows \\ Ellen Weissinger \\ University of Nebraska-Lincoln
}

This chapter will describe the results of a survey that assessed the self-perceived career goals and academic and professional development needs of master's and doctoral-level graduate students at the University of Nebraska-Lincoln. Both graduate students $(n=440)$ and graduate program coordinators $(n=23)$ were surveyed to provide an empirical basis for developing a strategic plan for graduate student academic and professional development activities. Results suggested that doctoral and master's students express different developmental needs, and that doctoral students' needs differed at different stages of their academic career. Implications for practice inherent in the survey findings are discussed, and the benefits of broadening the definition of graduate student training and development are examined.

\section{INTRODUCTION}

ecent research on the preparation of graduate students suggests that many Reel unprepared for the full range of academic and professional roles that they will face during their carcers (Golde \& Dore, 2001; National Research Council, 1992). Although reaching and research assistantships provide one form of training for future scholars, Austin (2002) found a general lack of systematic professional development opportunities available for graduate students, and Montell (1999) reported that a majority (68\%) of science doctoral students in an online survey were dissatisfied with the career preparation they received in their graduate programs. The notion that graduate education 
inadequately prepares students for their future career roles and responsibilities has prompted calls for an expanded understanding of the full spectrum of professional development needs of graduate students (Association of American Universities, 1998; Austin, 2002; Committee on Science, Engineering, and Public Policy, 1995; Golde \& Dore, 2001; National Association of GraduateProfessional Students [NAGPS], 2001).

This chapter will describe the results of a survey that assessed the professional development needs of master's and doctoral-level graduate students at the University of Nebraska-Lincoln (UNL). Both graduate students and graduate program coordinators were surveyed in this project, which was designed to provide an empirical basis for developing a strategic plan for graduate student academic and professional development activities. Also discussed are the implications for practice inherent in the survey findings and the benefits of broadening the definition of graduate student training and development.

\section{Related Literature on Graduate Student Development}

A number of recent studies have revealed what some investigators call a mismatch between the training doctoral students receive and the jobs they take (Golde \& Dore, 2001; NAGPS, 2001; Nerad \& Cerny, 1999, 2000). In 2001, NAGPS conducted a national survey in which a sample of graduate students was asked to report on their experiences in graduate school. Although an overwhelming majority of those responding to the survey reported high satisfaction with their doctoral programs and their advisors, survey participants reported inadequate preparation for both nonacademic and academic careers and a lack of appropriate preparation for teaching. Also, the authors noted that few students reported receiving training in the ethical standards and issues in their field despite increased attention at the national level to research ethics. Similarly, in a survey of Ph.D. alumni 10 years after receiving their degrees, respondents indicated that they needed help preparing for academic job interviews, writing a curriculum vita and cover letters, and suggestions on where to find job openings (Nerad \& Cerny, 1999, 2000). Respondents also reported that training in teamwork, collaboration, and interdisciplinary work would have helped them be more prepared for their current job responsibilities.

In their national survey of advanced Ph.D. students, Golde and Dore (2001) found that while the majority of respondents expressed a strong interest in a faculty career, there was a "three-way mismatch berween students goals, training and actual careers" (p. 5). In their report, the authors recommended major changes in graduate education to better prepare graduate students for their future careers, including a greater emphasis on teaching, more 
information about the job market, and support for those interested in nonacademic careers. Smith, Pedersen-Gallegos, and Riegle-Crumb (2002) examined relationships between graduate training, job satisfaction, and work of Ph.D. physical scientists and found that many of the graduates arrived on the job market ill-equipped to meet the challenges their new positions required. Only one-third of the respondents reported high levels of training in teaching and working in an interdisciplinary context, although the majority of respondents indicated that these two skills were important in their current work.

New visions of graduate education that involve broader definitions of graduate training and development have emerged. The new agenda includes preparing graduate students for future faculty roles, professional practice, or for careers in business, government, and industry. Graduate education that integrates a broad range of academic and professional development opportunities-from preparing students to teach to creating a forum for exploring ethical issues to providing a better understanding of the variety of institutions and organizations in which Ph.D.s work-can close the gap between traditional doctoral training and the work expected of those who obtain Ph.D.s.

Graduate student professional development begins the day students enroll in graduate studies and continues until they graduate. From learning how to be a successful graduate student (e.g., choosing an advisor, developing a plan of study) to developing advanced professional skills (c.g., supcrvising and mentoring undergraduate students, acquiring grant-writing skills), professional development encompasses a wide range of experiences beyond traditional disciplinary training. The ultimate goal of these activities is to help graduate students be more effective-and more marketable-in academia, business, government, or industry. However, an effective professional development program is more than career counseling or job placement services; it should focus on helping the graduate student develop a professional sense of self (Darwin, 2000). Professional development activities that include a process of reflection-for example, learning how to construct an academic portfolio-provide a context for exploring what it means to be a professional and helps graduate students articulate their own scholarly strengths and interests. Professional development experiences also can expand graduate students' thinking beyond the discipline, helping them devclop a broader definition of what it means to be a professional in their field (Darwin, 2000).

Since 1988, the UNL has had a strong instructional development program to meet the training and development needs of graduate teaching assistants and their departments (e.g., campus-wide TA workshops, the Institute for International Teaching Assistants, and individual instructional 
consultation). More recently, the Office of Graduate Studies recognized the need to provide a broader and more complex array of development activities (LaPidus, 1997). In 2002, the Office of Graduate Studies at UNL set out to develop a strategic plan for expanding graduate student academic and professional development programming. Before we took the first step in designing the new initiatives, however, we surveyed graduate students and the faculty members who serve as graduate program coordinators about the perceived academic and professional development needs of graduate students.

\section{An Assessment of Graduate Students' Academic and Professional Development Needs}

\section{Developing the Student Survey}

The purpose of the student survey was to learn more about UNL graduate students' self-perceived career goals and their academic and professional development needs. Both paper-and-pencil and web-based versions of the student survey were developed.

In order to create closed-ended survey items, we first developed a comprehensive list of future career goals and possible academic and professional development topics. To accomplish this, we drew from the literature on graduate student professional development and we searched web sites to identify a range of topics (e.g., cover letters, conference presentations, poster sessions, and grant writing). The final version of the student survey included 14 items related to future career goals, 16 items related to academic and professional development, and 9 items related to program delivery options. The survey's look and layout were modeled after a graduate student survey developed by the Center for Teaching Excellence at the University of California-Santa Cruz. The student survey was organized into two sections: About You and About Your Future (Appendix 17.1). The first section-About You-asked about the student's department, degree sought, number of years in graduate school, plans to pursue an academic career, and whether the respondent was currently teaching. The second section-About Your Future-included three parts: 1) respondents' future career goals, 2) possible academic and professional development topics that would help prepare them for the future, and 3) their preferred modes of delivery for development activities. For each area (future career goals, professional development topics, and delivery options) respondents were given a list of choices and were asked to mark all that applied to their situation. 


\section{Procedures for the Student Survey}

In September 2002, the Office of Graduate Studies emailed department graduate program coordinators asking for their help in distributing the survey to UNL graduate students. We distributed 1,133 hard copies of the survey to departments via campus mail; at the request of several departments, we made the survey available via the web as well.

\section{Results}

Useable data were obtained from 438 respondents ( 230 hard copies; another 208 surveys were completed online). Because we were not able to determine the exact number of online surveys distributed, it is not possible to calculate a response rate for the survey. As a broad comparison, 438 students represent $12.5 \%$ of the degree-seeking graduate students at UNL. Fifty percent of the respondents were currently seeking a master's degree $(n=220)$, while the other half indicated they were doctoral students $(n=218)$. This represents $11.5 \%$ of the master's students and $13.8 \%$ of the doctoral students at UNL. In addition, $48.2 \%$ of the students responding to the survey indicated that they were planning a career in academia; $33 \%$ of the respondents were currently teaching; and $48.3 \%$ of those not reaching indicated they planned to teach before they graduate.

\section{Student's Career Goals}

We listed 14 possible career paths and asked students to indicate their future career goals. Master's and doctoral student respondents most often selected "professor (Research I institution)" (32.7\%), "professor (Comprehensive Liberal Arts institution)" (31.3\%), and "research in a university" (27.7\%) as their future career goals. Table 17.1 shows a comparison of the top three career choices by Ph.D. and master's-level respondents.

TABLE 17.1

Top Three Career Goals

\begin{tabular}{lllc}
\hline $\begin{array}{c}\text { Ph.D. Respondents } \\
(\mathbf{n}=\mathbf{2 1 8})\end{array}$ & $\%$ & $\begin{array}{c}\text { Master's Respondents } \\
(\mathbf{n}=\mathbf{2 2 0})\end{array}$ & $\%$ \\
\hline Professor (Research I institution) & 42.7 & Industrial career & 22.9 \\
Professor (Comprehensivel & & & \\
Liberal Arts institution) & 34.4 & Consultant & 22.9 \\
Research in a university & 31.3 & Start own business & 22.9 \\
\hline
\end{tabular}


These findings are consistent with the results of the Golde and Dore (2001) survey of advanced Ph.D. students that suggested most doctoral students are primarily interested in a faculty career. In contrast, many masters' students in our sample aspired to nonacademic careers.

\section{Academic and Professional Development Needs}

Respondents were asked to choose the development topics that best fit their unique needs. A list of 16 possible academic and professional development topics was provided. Respondents most often selected "job market and interview strategies" (54.5\%), "curriculum vitae and cover letters" (48.4\%), "publishing in graduate school" (47.7\%), "writing a dissertation" (46.4\%), and "conference presentations" (44.8\%). Table 17.2 shows a comparison of the 16 topics by Ph.D. and master's-level respondents.

\section{TABLE 17.2}

Academic/Professional Development Topics

\begin{tabular}{llll}
\hline $\begin{array}{c}\text { Ph.D. Respondents } \\
\text { (n= 218) }\end{array}$ & $\%$ & \multicolumn{1}{c}{$\begin{array}{c}\text { Master's Respondents } \\
(\mathbf{n}=220)\end{array}$} & $\%$ \\
\hline Postdoctoral fellowships & 63.9 & Job market and interview strategies 57.8 \\
Writing a dissertation & 57.9 & Curriculum vitae and cover letters & 47.2 \\
Job market and interview strategies & 52.8 & Publishing in graduate school & 45.4 \\
Publishing in graduate school & 51.4 & Conference presentations & 43.1 \\
Curriculum vitae and cover letters & 50.9 & Alternative career opportunities & 40.4 \\
Conference presentations & 47.2 & Writing a dissertation & 35.8 \\
Grantsmanship & 45.8 & Preparing for industrial career & 33.5 \\
Teaching portfolio & 41.2 & Grantsmanship & 33.0 \\
Teaching/instructional strategies & 36.6 & Interdisciplinary research & 30.7 \\
Interdisciplinary research & 35.2 & Teaching/instructional strategies & 28.4 \\
Faculty roles/responsibilities & 31.0 & Professional ethics & 25.7 \\
Alternative career opportunities & 30.1 & Teaching portfolio & 22.5 \\
Preparing for industrial career & 28.7 & Faculty roles and responsibilities & 20.2 \\
Professional ethics & 23.1 & Postdoctoral fellowships & 19.7 \\
Academic citizenship & 17.6 & Academic citizenship & 18.3 \\
Other & 10.2 & Other & 10.6 \\
\hline
\end{tabular}


We took a closer look at the needs of doctoral students at different stages of their graduate program (first year, second year, third year, or fourth year or more). The rop three topics most often selected by students at different stages were:

- First year: "writing a dissertation" (61.1\%), "conference presentations" (55.6\%) and "publishing in graduate school" $55.6 \%$, and "postdoctoral fellowships" (55.6\%)

- Second year: "writing a dissertation" (72\%), "postdoctoral fellowships" $(60 \%)$, and "curriculum vitae" (56\%)

- Third year: "postdoctoral fellowships" (60\%), "job market and interview skills" (57.5\%), "publishing in graduate school" (57.5\%), and "writing a dissertation" (57.5\%)

- Fourth year or more: "postdoctoral fellowships" (76.8\%), "job market and interview skills" (59.4\%), and "writing a dissertation" (44.9\%)

\section{Figure 17.1}

Professional Development Topic by Program Stage for Ph.D. Students

$$
\text { ( } n=218)
$$

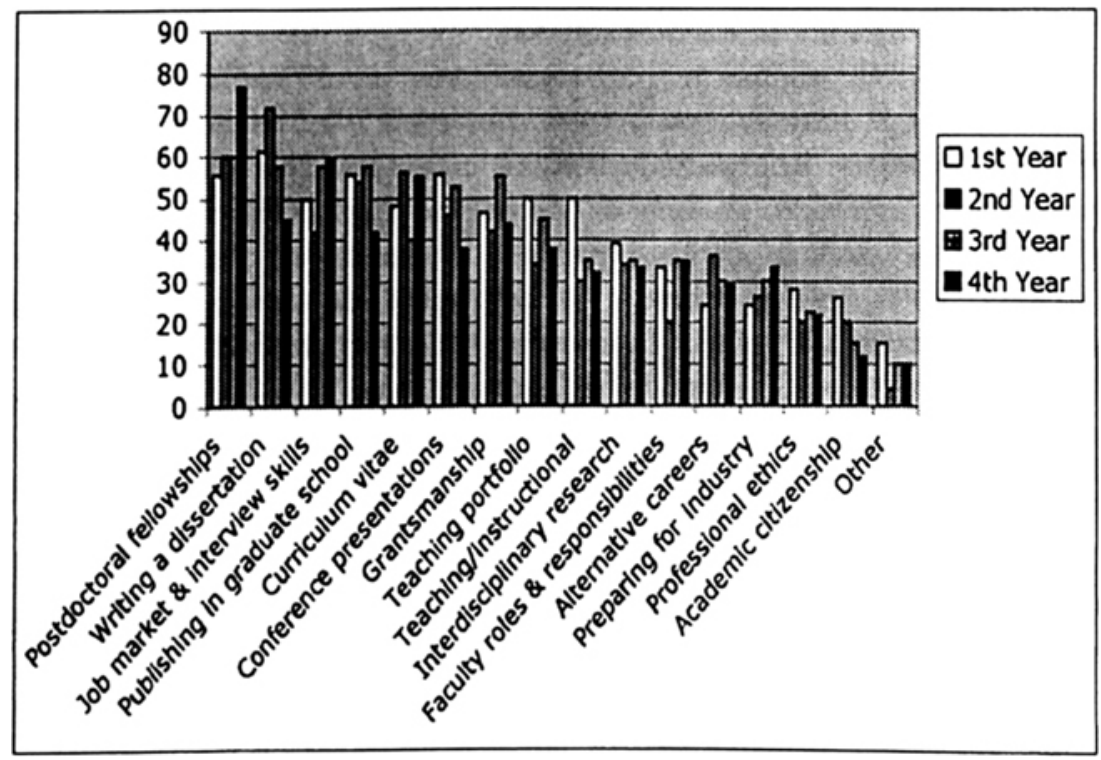




\section{Delivery Options for Development Activities}

We listed nine possible delivery methods and asked respondents about their preferences for experiencing development activities. Respondents most often chose "Internet resources" (40.5\%), "professional development seminars" (29.8\%), and "campus-wide workshops (interdisciplinary)" (28.9\%). Table 17.3 presents a comparison of the most frequently selected delivery methods by Ph.D. and master's respondents.

TABLE 17.3

Preferred Method of Delivery

\begin{tabular}{|c|c|c|c|}
\hline \multirow{2}{*}{$\begin{array}{l}\text { Ph.D. Respondents } \\
\qquad(\mathrm{n}=218)\end{array}$} & \multicolumn{3}{|c|}{ Master's Respondents } \\
\hline & $\%$ & $(n=220)$ & $\%$ \\
\hline Internet resources (web page) & 56.0 & Internet resources (web page) & 62.6 \\
\hline \multicolumn{4}{|l|}{ Campus-wide workshops } \\
\hline (interdisciplinary) & 47.8 & Online workshops & 46.0 \\
\hline Professional development & & Professional development & \\
\hline seminar(s) & 44.0 & seminar(s) & 43.2 \\
\hline
\end{tabular}

\section{Graduate Program Coordinators Survey}

We emailed UNL graduate program coordinators $(n=77)$ a list of 14 possible academic and professional development topics and asked them to select those that would interest their graduate students or that they thought represented a particularly important training or development need for their students. Twenty-three graduate chairs responded to the survey (response rate of 29.9\%). The topics that were most often selected included "job market and interview strategies" (91.3\%), "curriculum vitae and cover letters" (73.9\%), "conference presentations" (69.6\%), "grantsmanship" (65.2\%), and "writing a dissertation" (60.9\%).

Several graduate chairs suggested additional academic and professional development topics, including time management, technical writing skills, planning an academic career, basic communication/presentation skills, and balancing the demands of graduate school. 


\section{Using Graduate Student Needs Assessment Results to Design an Academic and Professional Development Program}

The graduate student survey and the graduate chairs' survey both provided important information about UNL graduate students' academic and professional development interests. We interpreted the results of our needs assessment in the context of recent studies that suggest different models for organizing graduate student preparation activities (Austin, 2002; Nyquist, 2002; Poock, 2001). From the national discussions on doctoral education, Nyquist compiled a set of core competencies that all Ph.D.s should be able to demonstrate: disciplinary knowledge; a commitment to an informed career choice; teaching competency; an understanding of diversity of students and workplaces; an understanding of the mentoring process; an ability to connect one's work to others; a global perspective; the ability to see oneself as a scholar-citizen; the ability to communicate and work in teams; and an understanding of ethical responsibilities as researchers, teachers, and professionals. Poock identified a similar set of five competency themes: communication, leadership, teaching and instruction, professional adaptability, and self-awareness. Austin suggested that graduate student development involves several dimensions which include various understandings, abilities, and skills. According to Austin, graduate students develop professional responsibilities as researchers, teachers, engaged scholars, and institutional/organizational citizens, and they develop professional identities in terms of being a faculty member, a professional, a member of the discipline, and a balanced and integrated individual.

Clearly, some of the understandings, skills, and abilities set forth by Austin, Nyquist, and Poock fall under the realm of departmental or discipline-specific training, while others can be effectively nurtured by a campuswide effort. For example, specific research processes and procedures are often developed at the department level, yet many graduate students would benefit from a general session on grant writing and grant management strategies. Similarly, pedagogical content knowledge - the understanding of pedagogical approaches to discipline or subject matrer (Shulman, 1986) - is best developed at the department level while more general teaching practices (understanding how students learn, assessment of student learning, teaching with technology, undergraduate advising) can be addressed at the campus level. Departments are in a better position to help graduate students understand the range of opportunities in which disciplinary expertise can be used while discussions at the campus level can help students understand the nature 
of academic appointments, the characteristics of students, and the different types of higher education institutions.

Based on the literature review and the results of the needs assessment, the Office of Graduate Studies developed a new initiative, the Graduate Student Academic and Professional Development Program. The goal of our program is to provide graduate students a diverse set of professional development activities to enhance the preparation they receive in their home departments. It is a centralized, integrated approach to professional development designed to supplement the good work being done at the department level, thereby strengthening graduate education at UNL. The program includes three major areas of emphasis: academic, career, and instructional development.

We learned from the survey that graduate students want additional opportunities to develop communication skills in areas such as grant writing and conference presentations. The academic development component includes workshops and resources on topics such as time management, how to publish in graduate school, and navigating the Ph.D. Departments interested in strengthening the research component of their graduate capstone courses can look to the Graduate Student Academic and Professional Development Program to help facilitate sessions on grant writing, technical report writing, and the ethical conduct of research.

The career development component helps graduate students explore the various academic and nonacademic career paths available to them. Workshops are offered in collaboration with other UNL units such as career services and the counseling and psychological services office. The career development component also includes the Preparing Future Faculty (PFF) program, a national initiative designed to better prepare those graduate students interested in an academic career.

Because the majority of the respondents indicated an interest in careers that include teaching, we believe it is important to supplement departmental teaching assistant training efforts. The instructional development component provides support services for graduate teaching assistants, including our annual campus-wide TA orientation, the Institute for International Teaching Assistants, and collaboration with academic departments to provide disciplinespecific training programs. Our graduate teaching assistants receive additional support through classroom observation and assistance with gathering student feedback for the purposes of documenting their teaching. Also, we are available to help departments provide systematic training and supervised experiences in teaching. 
Because students told us that they prefer some development activities to be delivered electronically, the Graduate Student Academic and Professional Development Program created additional support through online resources. We are currently preparing an online version of our Instructional Guide for University of Nebraska-Lincoln Teaching Assistants, and additional web resource materials, including online workshop modules, are being developed. A graduate student electronic list is another vehicle for delivering useful information and suggestions for how to navigate through graduate school, and we are using Blackboard to encourage cross-disciplinary discussions on professional development topics.

Our program also provides support to departments applying for federal training grants, both at the development and delivery stages. We help departments develop their training and teaching grant proposals and assist departments with the supervised instructional training support that many training grants require. By preparing students for diverse career opportunities, these training grants are another vehicle for broadening graduate education.

The results of this needs assessment have helped us think developmentally about graduate student professional development (Nyquist \& Sprague, 1998). For example, $72 \%$ of the doctoral students in their second year indicated an interest in the topic "writing a dissertation" while $77 \%$ of the doctoral students in their fourth year were more interested in learning about postdoctoral fellowships. From these findings, we can develop workshops for graduate students that are tailored to each stage of their careers.

\section{Ongoing Evaluation of the Graduate Student Academic and Professional Development Program}

Because many aspects of our program are still relatively new, we collect varied forms of ongoing evaluation data that can be used to refine our offerings. Program evaluation currently involves data collected at the end of each workshop. These are self-reported satisfaction indicators with open-ended comments that ask participants what new ideas, information, and/or approaches were learned during the workshop and "how likely" or "how prepared" they are to implement the strategies or processes discussed in the workshop.

Attendance data is another means of evaluating the extent to which a program is meeting its goals. We designed a database to track the number of graduate students and faculty mentors who currently use our program services. We record the following data: 1) general domain of consultation (academic, career, or instructional development), 2) consultation activity (e.g., provided resources, gave fecdback, videotaped class), and 3) when appropriare, specific 
consultation topic (e.g., teaching portfolio, diversity, instructional technology, vitae). Also, we keep registration records of workshop participants to track the specific kinds of students who participated in our programs and the departments we are serving. These records will be sorted at the end of the year and reports generated to help us track the resources expended for each activity and to help us plan more effectively (Chism, 1998).

Future program assessment will include follow-up surveys and possibly focus groups to measure the effectiveness in meeting the needs of graduate students and the impact on their graduate student experience at UNL.

\section{Professional Development for Graduate Students: IMPLICATIONS For Practice}

Increasingly, universities are restructuring their graduate programs to include a broader and more sophisticated menu of professional development opportunities (Gaff, 2002). Excellent examples of these innovative student development programs can be found at the University of California, Arizona State University, North Carolina State University, Northwestern University, University of Michigan, University of Texas-Austin, University of Colorado-Boulder, and University of Wisconsin-Madison. The PFF program is another example of a national professional development initiative that many universities have integrated into their training programs for advanced graduate students. Some universities, such as the University of Texas-Austin, have used their PFF program as a foundation for a more comprehensive professional development program (Cherwitz \& Sullivan, 2002).

While many of these programs are located in the graduate school, program administrators often rely on collaborative relationships between the graduate school and other campus programs to provide graduate students a range of professional development experiences. For example, Northwestern University's Beyond Books series-workshops that feature tips and advice to help graduate students navigate successfully through graduate school-is sponsored by the graduate school, the PFF program, the Searle Center for Teaching Excellence, university career services, and the student affairs division. Sharing resources in this way eliminates a major obstacle in providing professional development programs: increased resources (money and personnel) in a time of reduced budgets.

Another significant concern expressed by faculty and administrators is the fear that professional development activities will lengthen students' time to graduation. How can additional experiences be incorporated into doctoral training without taking time away from research and scholarship and without 
increasing time to degree? The answer will be different depending on the program and the institution. At UNL, participation in most of our workshops is voluntary, and we are considerate of both our graduate students' time and departmental concerns. We plan our program activities with a goal of optimizing the amount of time we ask of students while maximizing the benefits for our graduate students.

The benefits of offering a carefully designed comprehensive professional development program for graduate students far outweigh the drawbacks. Research indicates that graduate students who are integrated academically into their programs and into the campus community are more likely to complete their degrees than students who feel isolated and disconnected from the campus (Lovitts \& Nelson, 2000). And, recent reports on graduate education suggest that professional development programs will lead to increased student satisfaction with both their graduate experience and with their future careers (Golde \& Dore, 2001; Lovitts \& Nelson, 2000).

The nature of graduate education is changing. Greater emphasis is being placed on professional development of graduate students by professional organizations such as the Council of Graduate Schools, National Science Foundation, and the American Association of Colleges and Universities. The Professional and Organization Development Network in Higher Education (POD) has a storied history in offering instructional and professional development for faculty; more recently, the instructional development needs of teaching assistants have been emphasized in POD's strategic plan (i.e., the development of a TA developers committee). Perhaps the time has come for POD to adopt a broader definition of professional development to include graduate students, especially Ph.D.s and post-doctorates, and provide national leadership in developing programs and services to meet the specific needs of our future professionals.

\section{REFERENCES}

Association of American Universities. (1998). Committee on graduate education: Report and recommendations. Washington, DC: Author. Retrieved August 13, 2002, from http://www.aau.edu/reports/GradEdRpt.html

Austin, A. E. (2002). Preparing the next generation of faculty: Graduate school as socialization to the academic career. Journal of Higher Education, 73(1), 94-122.

Cherwitz, R. A., \& Sullivan, C. A. (2002, November/December). Intellectual entrepreneurship: A vision for graduate education. Change, 34(6), 23-27. 
Chism, N. V. N. (1998). Evaluating TA programs. In M. Marincovich, J. Prostko, \& F. Stout (Eds.), The professional development of graduate teaching assistants (pp. 249-262). Bolton, MA: Anker.

Committee on Science, Engineering, and Public Policy. (1995). Reshaping the graduate education of scientists and engineers. Washington, DC: National Academy Press.

Darwin, T. J. (2000). Professional development as intellectual opportunity. Paper presented at the National Communication Association Conference, Seattle, WA. Retrieved November 5, 2003, from https://webspace.utexas.edu/cherwitz/www/ ie/td.html

Gaff, J. G. (2002, November/December). Preparing future faculty and doctoral education. Change, 34(6), 63-66.

Golde, C. M., \& Dore, T. M. (2001). At cross purposes: What the experiences of today's graduate students reveal about doctoral education. Philadelphia, PA: Pew Charitable Trusts. Retrieved April 19, 2002 from http://www.phd-survey.org

LaPidus, J. B. (1997). Doctoral education: Preparing for the future. Washington, DC: Council of Graduate Schools. Retrieved September 10, 2002, from http:/l www.cgsnet.org/pdf/doctoraledpreparing.pdf

Lovitts, B. E., \& Nelson, C. (2000, November/December). The hidden crisis in graduate education: Atrrition from Ph.D. programs. Academe, 8Q(6). Retrieved May 9, 2004, from http://www.aaup.org/publications/Academe/2000/00nd/ND00LOVI.HTM

Montell, G. (1999). In on-line survey, graduate students in science rate their doctoral programs. Chronicle of Higher Education, p. A16.

National Association of Graduate-Professional Students. (2001). The 2000 national doctoral program survey. Washington, DC: Author. Retrieved September 10, 2002, from http://survey.nagps.org

National Research Council. (1992). Educating mathematical scientists: Doctoral study and the postdoctoral experience in the United States. Washington, DC: National Academy Press.

Nerad, M., \& Cerny, J. (1999, Fall). From rumors to facts: Career outcomes of English Ph.D.s. Council of Graduate Schools Communicator, 32(7), 1-11. Retrieved May 9, 2004, from http://www.grad.washington.edu/envision/PDF/Ten Years Later.pdf

Nerad, M., \& Cerny, J. (2000). Improving doctoral education: Recommendations from the "Ph.D.s 10 years later study." Council of Graduate Schools Communicasor, 33(2), 6. Retrieved May 9, 2004, from snet.org/PublicationsPolicyRes/ communicatorpdfs/2000/march2000.pdf 
Nyquist, J. D. (2002, November/December). The Ph.D.: A tapestry of change for the 21 st century. Change, 34(6), 12-20.

Nyquist, J. D., \& Sprague, J. (1998). Thinking developmentally about TAs. In M. Marincovich, J. Prostko, \& F. Stout (Eds.), The professional development of graduate teaching assistants (pp. 61-88). Bolton, MA: Anker.

Poock, M. C. (2001). A model for integrating professional development in graduate education. College Student Journah, 35(3), 345-353. Retrieved May 9, 2004, from http://articles.findarticles.com/p/articles/mi_m0FCR/is_3_35/ai_80744646

Shulman, L. S. (1986). Those who understand: Knowledge growth in teaching. Educational Researcher, 15, 4-14.

Smith, S. J., Pedersen-Gallegos, L., \& Riegle-Crumb, C. (2002). The training, careers, and work of Ph.D. physical scientists: Not simply academic. American Journal of Physics, 70(11), 1081-1092. 


\section{APPENDIX 17.1 \\ Graduate Student Survey}

\section{The Office of Graduate Studies Wants to Know: How Can We Help?}

We'd like 10 offer you a range of professional development activities that will help you prepore for your futwe-whether you're plowning a career in academia or industry. Please take a fow minudes to respond to this survey. When you're finished, just fold it bro thirds, staple t, and drop it in the canpus mall!

\section{About You:}

A. Department:

B. Citizenship: (e.8., U.S., Japan)

C. Degree(s) sought: Master's Ph.D. Other

D. Your level:

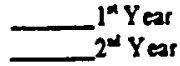
3⿻ Year $4^{*}$ or More

E. Do you plan to pursuc an academic career upon completion of your degree?

$$
\text { Yes _ No }
$$

F. Are you currently teaching?
If no, do you plan to teach before you graduate?
Yes
No
Yes $N_{0}$

\section{About Your Future}

G. Please indicate your future career goals. Mark al that apply.
D Professor (Reserch 1 institution)
D Professor (Comprehensive. Liberal Arts institution)
D Non-college teaching
Desearch in non-profit or goveramene
D Manager in non-profit ot government
(] Self-employment
$\square$ Other (please indicate):
D Professor (Community College)
D Research in privale sector
D Research in a university
D Start own business
D College administrator
a Industrial carcer
a Consultant

H. Here are some possible aodemic and professional development topies that we could explore. Check all those that interest you.
D Job market and interview strategies
D Professional ethics
D Developing a leaching portrolio
D Publishing in graduate school
D Postdoctoral fellow thips
D Teaching/instructional strategies
D. Faculty roles and responsibilities
D Altemative career opportu nities

a Grantmanship

a Ioterdisciplinary reserch and training opportunities

a Conference presentations

D Corriculum vitae and cover letters

D Writing a dissertation

- Preparing for industrial careers

O Academic citizemship (service 10 community)

[MORE ON BACK] 
1. What other topics would you like to explore in the context of workshops, seminars, or pedagogy courses?

J. How would you like to receive this assistancedinformation? Please check al that apply.

0 Campus-wide workshop (interdisciplinary)

Professional development seminar(s)

D Departmeni colloquium(s)

D Individual mentoring by department faculty
G Graduale Studies' pedagogy course

a Online workshop(s)

a Internet resources (web page)

D Individual menloring by senior graduate student(s)

D Other? Please list

$K$ Do you have any additional com ments or suggestions? 